\title{
AGRESSZÍV ÖNÉRVÉNYESÍTÉS VS. TÁRSAS FOGÉKONYSÁG: AZ ISKOLAI ZAKLATÁS AKTÍV SZEREPLŐINEK PSZICHODINAMIKAI VETÜLETE
}

\author{
AGGRESSIVE SELF-EFFICACY VS. SOCIAL \\ SUSCEPTIBILITY: THE PSYCHODYNAMIC \\ ASPECTS OF ACTIVE ROLE PLAYERS IN SCHOOL \\ BULLYING
}

Brassai László, Para Noémi

\begin{abstract}
The participant-role model analysis of school bullying is a relatively new approach in empirical social science. Our study is based on the analysis of the data of 154 students (average age 15.8 years) obtained by a mixed research method, which focused on the background factors of the active roles of school bullying (bullyers vs. protectors). Taking account of the socio-cultural and measurement-level limitations, we found self-efficacy to be a core factor of both bullying and protective behavior. At the same time, while bullying behavior was associated with aggression and competition, protective behavior was associated with prosocial behavior and communality.
\end{abstract}

Keywords: school bullying, aggression, competition, communality

\section{Elméleti bevezető}

A zaklatás a hatalom szisztematikus visszaélésével határozható meg, amelyben egy személy ismétlődő cselekvéseket hajt végre azzal a szándékkal, hogy bántson egy másikat, ami a kettejük viszonyában erőeltolódást eredményez (Olweus, 2013). Az áldozattá válás közvetlen kapcsolatba hozható a mentális egészségi állapottal: depresszióval, a szorongással, az öngyilkossági gondolatokkal és egyéb egészségrizikó viselkedésformákkal (Moore, Norman, Suetani, Thomas, Sly and Scott, 2017). A zaklatás következményeiben nem csupán az zaklató és az áldozat személye érintett, hanem a zaklatók táborába tartozók, az áldozat lehetséges és valós támogatói, sőt még a „kívülállók” is (Coloroso, 2020).

Az emberi agresszió tanulmányozása nagy múlttal rendelkezik, ennek a társadalomtudományok újabb diszkurzusaiban elkeresztelt jelensége: „a társas zaklatás” maga is számos magyarázó modellel bír már a pszichológiában. Ezek egyike - a legutóbbi időben egyre határozottabban körvonalazódó résztvevőiszerep modell - szerint a társas bántalmazás jelensége egy társas szintéren zajlik, amelynek valamennyi résztvevője egyaránt érintett - függetlenül attól, hogy a résztvevők aktív vagy passzív szerepet foglalnak-e el (Coloroso, 2020; Olweus, 2013). Az aktív szereplök protagonistája maga a bántalmazó, akit rendszerint szövetségesek öveznek, követnek (követők), támogatnak (aktív szövetségesek), helyeselnek (passzív szövetségesek). Az aktív szereplők egy meghatározó alakja a bátor szívü hős is, aki ellenzi a bántalmazást, s kész fellépni ellene, akár annak árán is, hogy a bántalmazóval és annak szövetségeseivel nyílt összetüzésbe kerüljön. Hozzá hasonlóan a bántalmazott táborába sorolható az érzelmi támogató személye is, aki bár nyíltszíni szerepet nem vállal ugyan, de a színfalak mögött a bántalmazottat együttérzéséről biztosítja. Ezen kívül a színtéren találjuk még a résztvevők között azokat, akiket a zaklatás jelensége érzelmileg megérint, de tétovák akár aktív, akár 
passzív szerepvállalásra, a bántalmazott mellett. Ez utóbbiak népes csoportot képeznek és a bullyingmenedzsment számára kihívást jelent feltárni azokat a tényezőket, amelyek együttes hatására Ök lehetséges támogatókká válhatnak, kiegyensúlyozva ezzel a bántalmazott vs bántalmazó erőmérlegét. Passzív szereplőnek számít még - mind a bántalmazott, mind pedig a bántalmazó tekintetében - a közönyös szemlélő, akit „hidegen hagy mások játéka”. A bántalmazott szenvedéséhez ridegséggel, a bántalmazó dominanciatörekvéséhez pedig érdektelenséggel viszonyul.

A bátor szívü hőssé válás lélektanának a tanulmányozása kihívás a társadalomlélektan számára. A zaklatás dinamikájának a megértése tekintetében a bátor szívü hős azonban csupán egyike csak az aktív szereplőknek. Ezért úgy gondoljuk, valahány aktív szereplő egyidejü vizsgálatára van szükség a zaklatók és védelmezők hátterének megismeréséhez.

A zaklatás a hatalom szisztematikus visszaélésével határozható meg, amelyben egy személy ismétlődő cselekvéseket hajt végre azzal a szándékkal, hogy bántson egy másikat, ami a kettejük viszonyában erőeltolódást eredményez (Olweus, 2013). Az áldozattá válás közvetlen kapcsolatba hozható a mentális egészségi állapottal: depresszióval, a szorongással, az öngyilkossági gondolatokkal és egyéb egészségrizikó viselkedésformákkal (Moore, Norman, Suetani, Thomas, Sly and Scott, 2017). A zaklatás következményeiben nem csupán az zaklató és az áldozat személye érintett, hanem a zaklatók táborába tartozók, az áldozat lehetséges és valós támogatói, sőt még a „kívülállók” is (Coloroso, 2020).

Az emberi agresszió tanulmányozása nagy múlttal rendelkezik, ennek a társadalomtudományok újabb diszkurzusaiban elkeresztelt jelensége: „a társas zaklatás” maga is számos magyarázó modellel bír már a pszichológiában. Ezek egyike - a legutóbbi időben egyre határozottabban körvonalazódó résztvevőiszerep modell - szerint a társas bántalmazás jelensége egy társas szintéren zajlik, amelynek valamennyi résztvevője egyaránt érintett - függetlenül attól, hogy a résztvevők aktív vagy passzív szerepet foglalnak-e el (Coloroso, 2020; Olweus, 2013). Az aktív szereplök protagonistája maga a bántalmazó, akit rendszerint szövetségesek öveznek, követnek (követők), támogatnak (aktív szövetségesek), helyeselnek (passzív szövetségesek). Az aktív szereplök egy meghatározó alakja a bátor szívü hős is, aki ellenzi a bántalmazást, s kész fellépni ellene, akár annak árán is, hogy a bántalmazóval és annak szövetségeseivel nyílt összetüzésbe kerüljön. Hozzá hasonlóan a bántalmazott táborába sorolható az érzelmi támogató személye is, aki bár nyíltszíni szerepet nem vállal ugyan, de a színfalak mögött a bántalmazottat együttérzéséről biztosítja. Ezen kívül a színtéren találjuk még a résztvevők között azokat, akiket a zaklatás jelensége érzelmileg megérint, de tétovák akár aktív, akár passzív szerepvállalásra, a bántalmazott mellett. Ez utóbbiak népes csoportot képeznek és a bullyingmenedzsment számára kihívást jelent feltárni azokat a tényezőket, amelyek együttes hatására Ök lehetséges támogatókká válhatnak, kiegyensúlyozva ezzel a bántalmazott vs bántalmazó erőmérlegét. Passzív szereplőnek számít még - mind a bántalmazott, mind pedig a bántalmazó tekintetében - a közönyös szemlélö, akit „hidegen hagy mások játéka”. A bántalmazott szenvedéséhez ridegséggel, a bántalmazó dominanciatörekvéséhez pedig érdektelenséggel viszonyul.

A bátor szívü hőssé válás lélektanának a tanulmányozása kihívás a társadalomlélektan számára. A zaklatás dinamikájának a megértése tekintetében a bátor szívü hős azonban csupán egyike csak az aktív szereplőknek. Ezért úgy gondoljuk, valahány aktív szereplő egyidejü vizsgálatára van szükség a zaklatók és védelmezők hátterének megismeréséhez.

\subsection{Az emberi társas viselkedés kultúrspecifikus aspektusai}

Hofstede (2011) felállított egy jól müködő rendszert az emberi társas magatartás kultúraközi eltéréseinek a megvilágítására. Értelmezésében minden kultúra-meghatározás magába foglal egy adott populációra vonatkozó íratlan viselkedési normákat és gondolkodásmódokat, amelyek az adott populációt megkülönböztetik más populációktól. Ezek a viselkedéssel kapcsolatos meggyőződésék kiindulópontját képezik a kollektív, de az egyéni céloknak egyaránt, és változatos formális és informális úton intézményesülnek. A meglévő kulturális normák pedig transzgenerációs módon átöröklődnek (Hofstede, i.m.). Hong, Benet-Martínez, Chiu és Morris (2003) szerint azonban a kultúra hatása az egyénre nem közvetlen, hanem közvetett módon valósul meg: egy hermeneutikai keretet jelent a valóság értelmezéséhez. Markus és Kitayama (1991) vizsgálati eredményei azt mutatják, hogy a nyugati kultúra béliek lényegesen nagyobb mértékben hajlanak az optimizmusra önmaguk 
boldogulását és jövőjüket illetően, és körükben sokkal elterjedtebbek az önbátorítás különféle stratégiái. A keleti kultúrában élők pedig önmagukat sokkal inkább a társas kapcsolatok, szerepek és feladatok kötelékében határozzák meg, mintsem az egyéni értékek viszonylatában. Mindezek a különbségek Markus és Kitayama (2003) szerint azzal magyarázhatók, hogy a keleti (Latin-amerikai, ázsiai és Kelet európai) és a nyugati (amerikai és Nyugat európai) kultúrában élők eltérő módon gondolkodnak önmagukról.

Hofstede (2011) értelmezésében az individualizmus-kollektivizmus egy kulturális dimenzió. Ugyanakkor az individualizmusnak vs. kollektivizmusnak, mint egyénszintű beállítódásnak a felfogása már a korai vizsgálatok tükrében is érvényt nyert. Így például Wagner (1992), az amerikai főiskolai hallgatók körében végzett tanulmányában a „társadalmi nemtörődömséget” egyénszintü változónak tekintette. Később mások (Chartman és Barsade, 1995; Moorman és Blakely, 1995) javasolták, hogy az individualizmus-kollektivizmus egyéni különbségként használható legyen a kulturális dimenzión belül is.

\subsection{A zaklatás kultúrspecifikus meghatározottságának egyénszintü összefüggései}

Az iskolai zaklatás tanulmányozása nemzetközi törekvéssé vált az elmúlt 20 évben (HBSC, 2020 Inchley és mtsai.; EUKO, 2020 - Smahel és mtsai.). A kutatások fényében (Smith, Kwak and Toda, 2016a) nyilvánvalóvá vált, hogy elterjedtségében és jellegében különbségek adódnak az egyes országok között. A határokon átnyúló különbségekre számos magyarázat adódik (Smith, Görzig and Robinson, 2018), így a kulturális értékek, az oktatási rendszer, a technológiai infrastruktúra, a szabályozási keret, a társadalmi-gazdasági rétegződés. Mindezek közül a kulturális értékek Hofstede (1980) által eredetileg felállított keretrendszere (az individualizmus vs. kollektivizmus dimenzió) az iskolai zaklatás Smith és munkatársai (2018) által meghatározó, ugyanakkor a nemzetközi szakirodalom által ez idáig alig kutatott háttértényezője.

Bergeron és Schneider 23 országot átfogó összehasonlító vizsgálata már 2005-ben rámutatott az individualizmus vs. kollektivizmus és a heteroagresszió összefüggésére. A talált összefüggést a szerzők azzal magyarázták, hogy amíg az individualista kultúrák tagjainál az agresszív magatartás egy gyakori önérvényesítési stratégia, addig a kollektivista kultúrákban - ahol a közösségiség meghatározó törekvés -, a heteroagresszió a csoport-harmóniát bomlasztó tényezőként nem kívánatos viselkedésforma. Hasonlóképpen érvelnek Ji, Zhang és Jones (2010) is Angliát (mind individualista) és Kínát (mind kollektivista) összehasonlító tanulmányukban. A talált összefüggések értelmezésében a hangsúly a szocializációs hatásokra helyeződik. A kollektivista kultúrákban például nagy hangsúlyt kap az önszabályozás. Ennek kialakítására a szülők már kora életkortól arra nevelik a gyermekeket, hogy társas közegben csak az elfogadott módon viselkedjenek, önkontrollt gyakorolva a szociálisan nem kívánatos személyes impulzusaik felett. Smith (Smith és mtsai., 2016; Smith, 2019) munkássága több ponton is adalékokkal szolgál az individualizmus vs kollektivizmus és az iskolai zaklatás összefüggéséről. Részint megerősítve az iskolakultúra, mint szocializációs szabályozótényező szerepét, részint pedig kihangsúlyozva az egyéni különbségeket. Smith rámutat arra, hogy bár a kollektivista kultúrákban a közösségi szellem harmonizálásának alárendelődő impulzivitáskontroll fokozza az egyéni alkalmazkodó képességet, ha a csoporton belüli zaklatás azonban mégis bekövetkezik, ez nagy horderejủ agresszióval jár együtt: kényszerítve az egyént a betagozódásra, vagy pedig kizárva őt a csoportból. Ugyanakkor rámutat arra, hogy a hagyományosan kollektivistának tekintett kultúrákban is megfigyelhető az iskolai zaklatás magasabb átlagértéke, például a feltörekvő társadalmi rétegbeli családok gyermekeinél.

\subsection{A zaklatás egyénspecifikus aspektusai}

Az evolúciópszichológiai kutatások tükrében a zaklató személyiség a legjobban a becsületesség és alázat alacsony szintjével jósolható be, amihez az árnyék-személyiség sötét magja társul: a pszichopátia, a narcizmus és a machiavellizmus (Muris, Merckelbach, Otgaar, and Meijer, 2017). Mindez a zaklató azon megnyilvánulásában tárgyiasul, hogy másokat saját érdekében kizsákmányoljon. Ashton, Lee és deVries (2014) szerint a zaklató személyisége abban különbözik a pszichopatáétól, hogy rá nem érvényes, hogy ne lenne tisztában az általa okozott következményekkel. Ehelyett rá inkább az érvényes, hogy felfogja ugyan a következményeket, csakhogy saját érdekei 
hajhászása közben ezekkel egyszerüen nem törődik. Ezért is állítja Rigby (2012), hogy az empátiafokozó prevenciós munka a zaklatók esetében kudarcra ítélt próbálkozás, hiszen a zaklatók esetében az empátia-hiány oka nem csupán egy fejletlen társas kompetencia (alacsony empátia), hanem egy rögzült személyiségvonás.

Világos tehát hogy a zaklatás agresszióval és versengő, hatalomra törő önérvényesítéssel társul (Kajonius, Persson and Jonason, 2015) ugyanakkor élesen elkülönül a mások felé forduló, segítőkészséggel fémjelzett proszocialitástól (Kaufman, Yaden, Hyde and Tsukayama, 2019). Ezért is a Mentális Rendellenességek Diagnosztikai és Statisztikai Kézikönyvének legújabb kiadásába (DSM5) (APA, 2013) a „korlátozott proszociális érzelmek” megnyilvánulás a zaklató viselkedés egyik jelölőjeként szerepel. Témánk szempontjából azonban megválaszolatlan kérdés az énhatékonyság és versengés szerepe a zaklató magatartással ellentétes védelmező magatartásban. Zimbardo és munkatársai (Zimbardo, 2018; Franko, Blau and Zimbardo, 2011) rámutatnak arra, hogy a védelmezö (hősies) magatartáshoz az önbecsülés magas szintjére és önérvényesítő indíttatásra van szükség, akárcsak a zaklató magatartás esetében. Ezért is a hösiességet határozottan megkülönbözteti az altruizmustól.

A szakirodalmi áttekintés arra enged tehát következtetni, hogy a zaklató és védelmező magatartás megkülönböztető, de közös jegyeket is egyaránt magába foglal. Vizsgálatunk e két magatartásforma hátterében meghúzódó agresszióval társuló versengő egyénorientáció vs. proszocialitással társuló közösségorientáció szerepének az elemzésére összpontosul.

\section{A kutatás módszertana}

\subsection{Résztvevők és adatfelvétel}

Vizsgálatunk alanyai Kovászna megye VII-XII osztályos tanulói. Az adatfelvétel két módszerre támaszkodott: a tanulókat megcélzó önkitöltős kérdőívre, illetve a pedagógusoknak címzett osztályfőnöki értékelöre. Az adatfelvétel 2020 novemberében történt. A google docs alatt készített online önkitöltős kérdőivet 560 VII-XI osztályos tanuló töltötte ki. Az osztályfőnöki értékelöt 11 osztályfönök végezte el. Az adatfelelemzés csak azon tanulók kérdőíves válaszaira terjedt ki, akik részéről rendelkeztünk osztályfőnöki értékeléssel is. Így az elemzett minta nagysága 154 tanuló (átlagéletkor 15,8 év, nemek aránya 56\% fiú illetve 44\% lány) volt.

\subsection{Alkalmazott mérőeszközök}

\subsubsection{Osztályfőnöki értékelő}

Az osztályfőnököket egyénileg kerestük meg. Az első találkozás alkalmával ismertettük velük a vizsgálat célját, módszereit, valamint az osztályfőnökök adatgyüjtésben betöltendö szerepét. Egy általunk megadott szempontrendszer szerint csoportosítaniuk kellett az osztályukban tanuló diákokat, az alábbiak szerint:

„Adott a következő társas helyzet: K-t gúnyolják, piszkálják, zaklatják, föként $\mathrm{F}$ és társai. Van, hogy nemcsak szavakkal, hanem tettekkel is. Nem csupán, amikor együtt vannak, hanem online is folyamatosan keresztbe tesznek neki, lehurrogják, szívatják. Ebben a dologban F-nek szövetségesei vannak, akik együtt mókáznak a vezérrel. Ismételt cselszövések árán, sikerül elérniük, hogy K ne érezze jól magát a bőrében, kiszoruljon a közösségből.

Kérjük, állapítsa meg minden egyes diákjára nézve, hogy az iskolai zaklatás fentihez fogható helyzeteiben milyen szerepet tölt be:

- bántalmazott - a bemutatott vagy ahhoz hasonló helyzetben Ö K

- bántalmazó - a bemutatott vagy ahhoz hasonló helyzetben Ö F

- követő -aktívan bekapcsolódik a „mókába”, hogy kifogjanak K-n

- aktív szövetséges - a bemutatott vagy ahhoz hasonló helyzetben aktívan nem száll be a „mókába”, de amint F elhagyja a terepet nyíltan helyesli az általa indított akciókat ezzel F felé nyíltan kifejezve, hogy érzelmileg mellette áll 
- passzív szövetséges - távolról kiélvezi a helyzetet

- közönyös bámészkodó - Öt „nem érdekli”, hogy mit csinálnak mások egymás között

- lehetséges védelmezö - érzelmileg felkavarja, ahogyan egyesek (F és társai) másokkal bánnak, de cselekvésképtelen

- érzelmi támogató - nyilvánosan passzív, de privátba együttérző, érzelmileg támogató üzeneteket küld a bántalmazott felé

- bátor szívü hős - nyíltan fellép a bántalmazás ellen, ha a helyzet úgy adja, a bántalmazott pártját fogja a bántalmazóval szemben

\subsubsection{Az önkitöltős kérdőív}

Alkalmazkodva a világjárvány megszorításaihoz, kérdőívünket a google forms felületen szerkesztettük. A kérdőívet az osztályfőnök online osztotta meg a diákokkal. A válaszadás önkéntes módon történt, névtelen.

\section{A kérdőív skálái a következők voltak:}

Az egyénvezérelt vs. közösségvezérelt beállítódás mérése Triandis és Gelfand (1998) elméletéböl kiindulva két darab kétpólusú kijelentés segítségével valósult meg. Az első Függetlenség vs. Kölcsönösség dimenzióra vonatkozott. (Példa item „Nekem nagyon fontos, hogy érezzem, önmagam lehetek, független mindenkitöl” vs. „Nekem nagyon fontos, hogy érezzem a kapcsolatot másokkal.”). A második dimenzió az Egyéni jóllét vs. Közösségi jollétre vonatkozott (Példa item: „Ahhoz, hogy jól érezzem magam nekem elég, ha én jól vagyok” vs. „Akkor érzem jól magam, ha a körülöttem lévők is jól vannak.”. A mérőeszköz itemeinek feldolgozása dichotomizált változóként valósult meg.

A proszocialitás vizsgálatára a Pulkkinen, Kaprio és Rose (1999) által jegyzett Többdimenziós Kortárs Nominalizációs Tár felhasználásával történt. Segítségével három proszociális viselkedésforma mérésére került sor: az egyik a konstruktív magatartás (Példa item: „Szeretem magam körül rendbe hozni a dolgokat anélkül, hogy erre valaki kimondottan kérne.”, a másik a segítőkészség (Példa item: „Ha látom, hogy valaki segítségre szorul, nem várom meg, hogy kérje is azt, rögtön ott termek, hogy segítsem Öt”, a harmadik az együttműködés (Példa item: „Kíváncsi vagyok mások gondolataira, megoldásaira, ezért jó kedvvel társulok hozzuk a munkavégzésben”). A tanulóknak ötfokú Likertskála segítségével kell megállapítaniuk az adott kijelentések önmagukra vonatkoztatott érvényességét, ahol az „egyáltalán nem érvényes rám” válaszlehetöség 1 pontot, a „teljes mértékben érvényes rám” válaszlehetőség pedig 5 pontot ért. Az elérhető minimum pontszám 9, a maximum pontszám pedig 45 volt. Az elért pontokat összesítve indexet számítottunk. Mintánkban a skála Cronbach alfa értéke 0,92 volt.

Az énhatékonyság vizsgálatára Schwarzer és Jerusalem (1995) által kidolgozott Én-hatékonyság Skálát alkalmaztuk. A tanulóknak ötfokú Likert-skála segítségével kell megállapítaniuk adott kijelentések önmagukra vonatkoztatott érvényességét, ahol az „egyáltalán nem érvényes rám” válaszlehetőség 1 pontot, a „teljes mértékben érvényes rám” válaszlehetőség pedig 5 pontot ért. Példaitem: Mindig sikerül megoldani a problémáimat, ha nagyon akarom. Az elérhető minimum pontszám 10, a maximum pontszám pedig 50 volt. Az elért pontokat összesítve indexet számítottunk. Mintánkban a skála Cronbach alfa értéke 0,91 volt.

A Reaktív-proaktív agresszió mérésére Raine, Dodge, Loeber, Gatzke-Kopp, Lynam, Reynolds, Strouthamer-Loeber, és Liu. (2006) skáláit alkalmaztuk. A tanulóknak ötfokú Likert-skála segítségével azt kellett megítélniük, hogy az kérdőív itemei milyen mértékben voltak rájuk jellemzők az elmúlt időben. Mindkét skála külön-külön hét itemet tartalmazott. Példaitem a reaktív agresszióra: „Mások kárát kívántad, mert haragudtál rájuk.” Példaitem a proaktív agresszióra: „Csalódtál másokba, amiért ki is fejezted a dühöd.” A tanulóknak ötfokú Likert-skála segítségével kell megállapítaniuk adott kijelentések önmagukra vonatkoztatott érvényességét, ahol az „egyáltalán nem érvényes rám” válaszlehetőség 1 pontot, a „teljes mértékben érvényes rám” válaszlehetőség pedig 5 pontot ért. Az elérhető minimum pontszám 7, a maximum pontszám pedig 35 volt. Az elért pontokat összesítve 
indexet számítottunk. Mintánkban a skála a reaktív agresszió skála Cronbach alfa értéke 0,89 volt, a proaktív agresszió skála Cronbach alfa értéke pedig 0,90 volt.

A ridegség mérésére a Kimonis, Frick, Muñoz és Aucoin (2008) Ridegség és Érzéketlenség Kérdőívét használtuk fel. A tanulóknak ötfokú Likert-skála segítségével kell megállapítaniuk adott kijelentések önmagukra vonatkoztatott érvényességét, ahol az „egyáltalán nem érvényes rám” válaszlehetőség 1 pontot, a „teljes mértékben érvényes rám” válaszlehetőség pedig 5 pontot ért. (Példaitem: „Amit én „helyesnek” vagy „helytelennek” gondolok, az különbözik attól, amit mások gondolnak.”). Az elérhető minimum pontszám 7 , a maximum pontszám pedig 35 volt. Az elért pontokat összesítve indexet számítottunk. Mintánkban a skála Cronbach alfa értéke 0,91 volt.

A versengés vizsgálatára Ryckman, Kaczor, és Gold (1990) által kidolgozott Hiperversengő Attitüd Skálát és az Önfejlesztő Versengés Attitüd Skálát használtuk fel. Mindkét skála egyenként hét itemet tartalmazott. Példaitem: „Ha nyerek, máris erősebb személynek érzem magam.” illetve „Inkább azért élvezem a versengést, mert mozgósít, hogy kihozzam magamból a legjobbat, és nem annyira azért, hogy általa mások fölé kerekedjek.”). A tanulóknak ötfokú Likert-skála segítségével kell megállapítania adott kijelentések önmagukra vonatkoztatott érvényességét, ahol az „egyáltalán nem érvényes rám” válaszlehetőség 1 pontot, a „teljes mértékben érvényes rám” válaszlehetőség pedig 5 pontot ért. Az elérhető minimum pontszám 7, a maximum pontszám pedig 35 volt. Az elért pontokat összesítve indexet számítottunk. Mintánkban a Hiperversengő Attitüd Skála Cronbach alfa értéke 0,90 volt, az Önfejlesztő versengés Attitüd Skáláé pedig 0,89 .

\subsection{Adatfeldolgozás}

Az adatok feldolgozása az IBM SPSS for Windows 26.0 programcsomag segítségével történt. Az adatelemzésnél legfeljebb 95\%-os hibaküszöböt tartottunk elfogadhatónak. Az adatelemzést az iskolai zaklatással kapcsolatos viselkedéses reakciók gyakoriságszámításával indítottuk. Ezt követően az iskolai zaklatás szereplőit két csoportba tömörítettük: a bántalmazók és a védelmezők csoportjába, a vizsgált háttérváltozók tömörülését pedig faktoranalízissel vizsgáltuk. Az összefüggésekre összpontosuló adatelemzést regresszióanalízisre alapoztuk. Tekintve, hogy a függő változóink dichotomizált változók, a független változók között pedig nominális és ordinális változók is voltak, binális logisztikus regresszióelemzés mellett döntöttünk. Célunk az volt, hogy beazonosítsuk az Bántalmazók és a Védelmezők regressziós modelljének kockázati- és védőfaktorait. A binális logisztikus regresszióanalízis során esélyhányadosokat számítottunk 95\%-os küszöbön határozva meg a konfidenciaintervallumot. Az 1 feletti esélyhányados-értékek növelik a független változó előfordulásának a valószínüségét - esetünkben a védelmező viselkedésformáét -, az 1 alatti értékek pedig csökkentik azt, egyben növelve a bántalmazó viselkedésforma elöfordulásának esélyét.

\section{Eredmények}

Mintánkban az iskolai zaklatási helyzetben tanúsított viselkedésformák legnépesebb csoportját a közönyös bámészkodók (35 személy) és a bántalmazottak (21 személy) teszik ki (lásd. 1. táblázat). Bántalmazó besorolást mindössze 11 tanuló kapott.

1. táblázat. Az iskolai zaklatással kapcsolatos viselkedésformák gyakorisági megoszlása $(\mathrm{N}=154)$

\begin{tabular}{|c|c|c|c|}
\hline \multirow[t]{2}{*}{ Viselkedésformák } & \multirow[t]{2}{*}{ Esetszám } & \multicolumn{2}{|c|}{ Derivált változók } \\
\hline & & Bántalmazók & Védelmezők \\
\hline Bántalmazó & 11 & 11 & \\
\hline Bántalmazott & 21 & & \\
\hline Követő & 11 & 11 & \\
\hline Aktív szövetséges & 12 & 12 & \\
\hline Passzív szövetséges & 14 & & \\
\hline Lehetséges védelmező & 13 & & \\
\hline Érzelmi támogató & 17 & & 17 \\
\hline Bátor szívű hős & 12 & & 12 \\
\hline Közönyös bámészkodó & 35 & & \\
\hline 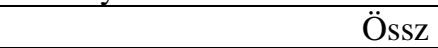 & & 42 & 29 \\
\hline
\end{tabular}


A kutatásunk céljának a tekintetében fontos bántalmazó vs. védelmező változók kialakítása a következőképp valósult meg: bántalmazók = bántalmazó, követő, aktív szövetséges, összességében 42 tanuló, védelmezők = érzelmi támogató, bátor szívü hös, összességében 29 tanuló.

Mintánkban a vizsgált folytonos háttérváltozók tömörülésének elemzésére faktoranalízist alkalmaztunk.

2. táblázat. A vizsgált háttérváltozók faktoranalízise nyomán kialakult faktorok és faktorsúlyok $(\mathrm{KMO}>0,6)(\mathrm{N}=154)$. A táblázatban a Kaiser-kritérium szerinti $(>0,3)$ faktorsúlyokat kiemeltük.

\begin{tabular}{|l|l|l|l|}
\hline Háttérváltozók & \multicolumn{1}{|c|}{$\begin{array}{c}\text { I Faktor } \\
\text { proszocialitás }\end{array}$} & $\begin{array}{c}\text { II Faktor } \\
\text { Agresszivitás }\end{array}$ & $\begin{array}{c}\text { III. Faktor } \\
\text { onérvényesítés }\end{array}$ \\
\hline Konstruktív magatartás & $\mathbf{0 , 7 9 4}$ & $-0,195$ & 0,095 \\
\hline Segítőkészség & $\mathbf{0 , 8 0 4}$ & $-0,187$ & 0,012 \\
\hline Együttmüködés & $\mathbf{0 , 7 8 7}$ & $-0,189$ & 0,076 \\
\hline Szociális aktivitás & $\mathbf{0 , 7 6 7}$ & 0,203 & 0,211 \\
\hline Reaktív agresszió & $-0,182$ & $\mathbf{0 , 8 0 5}$ & $-0,199$ \\
\hline Proaktív agresszió & 0,021 & $\mathbf{0 , 8 3 7}$ & 0,215 \\
\hline Ridegség & $-0,225$ & $\mathbf{0 , 7 0 1}$ & 0,096 \\
\hline Hiperversengő attitüd & $-0,200$ & $\mathbf{0 , 5 4 2}$ & $-0,168$ \\
\hline Énhatékonyság & 0,163 & $\mathbf{0 , 6 6 2}$ & $\mathbf{0 , 7 6 3}$ \\
\hline Önfejlesztő versengés & 0,050 & 0,211 & $\mathbf{0 , 7 3 1}$ \\
\hline
\end{tabular}

A 2. táblázatban a vizsgált háttérváltozók faktorstruktúráját szemlélteti. A faktoranalízist varimax rotációval végeztük, és az 1-nél nagyobb sajátértékkel rendelkező faktorváltozókat vontuk be a struktúra értelmezésébe, azaz ennek alapján határoztuk meg a faktorok végső számát. Így három faktort kaptunk, amelyek együttvéve a jelenség összvarianciájának 54\%-át magyarázzák. Az első faktor a proszociális viselkedésformákat egyesíti. A második faktorban az agresszivitás formái a hiperversengő attitüddel együtt jelennek meg. Tekintve, hogy e faktoron az agresszivitás formái ülnek nagyobb faktorsúllyal, a faktort agresszivitás faktornak neveztük el. Végül, a harmadik faktor az önfejlesztő versengést és az énhatékonyságot foglalja magába. E faktorban helyet kapó változókat tekintve a harmadik faktort önérvényesítés faktornak neveztük el. Kiemelendő, hogy az énhatékonyság a kettes és hármas faktorokban is helyet foglal.

A vizsgált háttértényezőknek a zaklató vs. védelmező magatartással összefüggő kapcsolatának a vizsgálatára regresszióanalízist futtattunk. Az eredmények a fényében a vizsgált háttérváltozók mindenike prediktornak bizonyult (lásd. 3. táblázat).

3. táblázat A vizsgált háttérváltozók összefüggése a bántalmazó vs. védelmező magatartással $(\mathrm{N}=71)$

\begin{tabular}{|l|l|l|}
\hline & Esélyhányados & Konfidencia intervallum \\
\hline Proszocialitás faktor & 2,56 & $(1,84-2,37)^{* * *}$ \\
\hline Agresszivitás faktor & 0,89 & $(0,78-0,96)^{* * *}$ \\
\hline Önérvényesítés faktor & 1,59 & $(1,37-1,63)^{* * *}$ \\
\hline $\begin{array}{l}\text { Függetlenség vs. összekötöttség } \\
l=f u ̈ g g e t l e n s e ́ g\end{array}$ & 2,31 & $(2,01-2,48)^{* * *}$ \\
\hline $\begin{array}{l}\text { Egyéni vs. közösségi jollét } \\
l=\text { egyéni jollét }\end{array}$ & 2,27 & $(2,07-2,39)^{* * *}$ \\
\hline
\end{tabular}

$* * * p<0,001$

Az agresszivitás faktor növeli a bántalmazó magatartás előfordulásának a valószínúségét, a további négy független változó pedig a védelmező magatartás előfordulását favorizálja. A legmeghatározóbb védőfaktornak a proszocialitás faktor és a közösségiség változók bizonyultak. Ennek értelmében a proszocialitás például két és félszer növeli a védelmező magatartás előfordulásának az esélyét, a közösségiség két változója: az összekötöttség és a közösségi jóllét pedig közel hasonló mértékben bizonyult védőtényezők. 


\section{Következtetések}

Az agressziókutatás nagy múltra tekint vissza a pszichológiában. Ennek sajátos formája a zaklatás, melynek megkülönböztető sajátosságai: az egyenlőtlen erőviszonyok, a szándékosság és az ismétlődés (Olweus, 2013). Kutatásunkban az iskolai zaklatást Coloroso, Olweus és Zimbardo munkássága által fémjelzett résztvevői-szerep modell szerint tárgyaltuk, az elvégzett elemzéseket pedig a résztvevők két aktív táborának: a bántalmazók és védelmezők pszichológiai háttértényezőinek a feltárására összpontosítottuk. Tanulmányunkban a zaklatás jelenségének előbb említett aktív magatartásformáit az agresszióval, a versengéssel, az énhatékonysággal, a proszocialitással illetve az individualista vs kollektivista orientációval hoztuk összefüggésbe. Az áttekintett szakirodalom által igazolt összefüggések mellett kutatásunk rámutatott a bántalmazó és a védelmező magatartás hátterében húzódó azonos és eltérő lelki működésmódokra.

A kultúra viselkedésformáló, -mediáló és -moderáló hatása alaposan dokumentált (Hofstede, 2010; Markus és Kitayama, 1991, 2003). A szocializáció, mint kulcsfontosságú moderáló tényező szerepének a megvilágításával érthetőbbé válnak makrokulturális hatások egyénspecifikus megnyilvánulásai (Chartmann és Barsade, 1995; Moorman és Blakely, 1995; Wagner, 1992). Így például az individualista vs. kollektivista orientáció összefüggése a heteroagresszióval, ezen belül is a zaklató magatartással (Bergeron és Schneider, 2005; Ji és mtsai., 2010; EUKO, 2020; HBSC, 2020). Ezirányú empirikus vizsgálatok a zaklatást az individualisztikus beállítódással társították (Smith és mtsai., 2016; 2018; Smith, 2019). Saját vizsgálatunk egybecseng a nemzetközi eredményekkel és azt tükrözi, hogy az egyénszintü invidualista beállítódás a bántalmazó magatartással, míg a közösségközpontú beállítódás a védelmező magatartással jár együtt.

A bántalmazó viselkedés kapcsolata az agresszivitással valamint a versengéssel, és a védelmező magatartás kapcsolata a proszocialitással a szakirodalomban tisztázott kérdés (Kajonius és mtsai., 2015; Kaufman és mtsai., 2019; Zimbardo, 2019). A versengő viselkedés egyes formáinak a szerepe a védelmező magatartásban viszont már nem. Kutatásunk e tekintetben adalékokkal szolgál a védelmező magatartás lelki dinamikájának a megértésére nézve. Eredményeink arra mutatnak rá ugyanis, hogy a védelmezők - akárcsak a bántalmazók - jó énhatékonysággal bírnak. A védelmezésben a bántalmazáshoz hasonlóan ott munkál tehát a versengés szellemisége. Ez minden bizonnyal egy olyan indíték, amely viselkedés-dinamikailag megalapozza a védelmező „színre lépését” (Zimbardo, 2018). Csakhogy amíg az énhatékonyság a bántalmazás vs. védelmezés közös háttérváltozója, a versengés megkülönböztető tényezőnek bizonyul. Míg a bántalmazó magatartásban versengés a másik fél legyőzésének, az előnyszerzésnek az indítékával fütött hiperversengő attitüd formájában van jelen, addig a védelmező magatartásban a lelki növekedés motívumával összefonódó önfejlesztő versengés formájában érhető tetten.

Összefoglalásképpen megállapíthatjuk tehát, hogy az iskolai zaklatás tekintetében mind a bántalmazó, mind pedig a védelmező magatartás foganatosítása szükségelteti az énhatékonyságot. Csakhogy, amíg a „színrelépés” a zaklató magatartás esetében dominanciaszükséglettől fütött agresszív önérvényesítéssel, a védelmezés esetében az segítőkészséggel, konstruktivitással, együttmüködéssel fémjelzett proszocialitással, valamint azzal összefonódó közösségiséggel társul.

Tekintve, hogy eredményeinket keresztmetszeti adatgyüjtésből nyertük, nem áll módunkban okokozati kapcsolatok megállapítása. Ennek hiányában a vizsgálatunk nyomán megfogalmazott következtetések kétoldalú összefüggések kontextusában értelmezendők. A talált eredmények validitását gyengíti az individualista vs. kollektivista változó alacsony mérési szintje. Bár adatainkat erdélyi mintából nyertük, eredményeink kiterjeszthetőségének további akadályát jelentik a vizsgált populáció szocio-kulturális sajátosságai. A bántalmazók és a védelmezők differenciált elemzése a jövőben újabb adalékokkal szolgálhat az egyes változók szerepéről és relatív súlyáról. Hasonlóképpen további adatokat nyerhetünk egyéb változók bevonásával (például értékorientáció, remény, családon kívüli szocializációs ágensek). 


\section{Irodalomjegyzék}

Ashton, M.C., Lee, K., de Vries, R.E. (2014): The HEXACO Honesty-Humility, Agreeableness, and Emotionality Factors: A review of research and theory. Personality and Social Psychology Review, 18, 139-152.

Bergeron, N., Schneider, B.H. (2005): Explaining cross national differences in peer-directed aggression: a quantitative synthesis. Aggressive Behavior, 31, 116-137.

Chatman, J.A., Barsade, S. (1995): Personality, organizational culture and cooperation: Evidence from a business simulation. Administrative Science Quarterly, 40, 423-443.

Diagnostic and Statistical Manual of Mental Disorders, 5th Edition (2013): American Psychiatric Association.

Coloroso, B. (2020): Zaklatók, áldozatok, szemlélök: az iskolai eröszak. Óvodától középiskoláig: Hogyan szakithatjuk meg az eröszak körforgását és teremthetünk összetartóbb közösséget? Harmat Kiadó, Budapest.

Franko, Z.E., Blau, K., Zimbardo, P.G. (2011): Heroism: A conceptual analysis and differentiation between heroic action and altruism. Review of General Psychology, 15, 99-113.

Hawes, D.J., Price, M.J., Dadds, M.R. (2014): Callous-unemotional traits and the treatment of conduct problems in childhood and adolescence: A comprehensive review. Clinical Child and Family Psychology Review, 17, 248-267.

Hofstede, G. (2011). Dimensionalizing cultures: The Hofstede model in context. Online Readings in Psychology and Culture, 2(1).

Hong, Y.Y., Benet-Martínez, V., Chiu, C.Y., Morris, M.W. (2003): Boundaries of cultural influence. Construct activation as a mechanism for cultural differences in social perception. Journal of CrossCultural Psychology, 34, 453-464.

Inchley, J., Currie, D., Budisavljevic, S., Torsheim, T., Jåstad, A., Cosma, A. et al. (Eds.) (2020): Spotlight on adolescent health and well-being. Findings from the 2017/2018 Health Behaviour in School-aged Children (HBSC) survey in Europe and Canada. International report. WHO Regional Office for Europe.

Ji, L., Zhang, W., Jones, K. (2016): Children's experience of and attitudes towards bullying and victimization: a cross-cultural comparison between China and England. In P K Smith, K Kwak, Y Toda (Eds.), School bullying in different cultures: eastern and western perspectives (pp. 170-188). Cambridge: Cambridge University Press.

Kajonius, P.J., Persson, B.N., Jonason, P.K. (2015): Hedonism, achievement, and power: universal values that characterize the Dark Triad. Personality and Individual Differences, 77, 173-178.

Kaufman, S.B., Yaden, D.B., Hyde, E., Tsukayama, E. (2019): The light vs. dark triad of personality: Contrasting two very different profiles of human nature. Frontiers in Psychology, 10, article 467.

Kimonis, E.R., Frick, P.J., Muñoz, L.C., Aucoin, K.J. (2008): Callous-unemotional traits and the emotional processing of distress cues in detained boys: Testing the moderating role of aggression, exposure to community violence, and histories of abuse. Development and Psychopathology, 20, 569589.

Markus, R.H., Kitayama, S. (2003): Culture, self, and the reality of the social. Psychological Inquiry, $14,277-283$.

Markus, R.H., Kitayama, S. (1991): Culture and the self: Implications for cognition, emotion, and motivation. Psychological Review, 98, 224-253.

Moore, S.E., Norman, R.E., Suetani, S., Thomas, H.J., Sly, P.D., Scott, J.G. (2017): Consequences of bullying victimization in childhood and adolescence: A systematic review and meta-analysis. World Journal of Psychiatry, 7, 60-76. 
Moorman, R.H., Blakely, G.L (1995): Individualism-collectivism as an individual difference as predictor of organizational citizenship behavior. Journal of Organizational Behavior, 16, 127-142.

Muris, P., Merckelbach, H., Otgaar, H., Meijer, E. (2017): The malevolent side of human nature: a meta-analysis and critical review of the literature on the Dark Triad (narcissism, Machavellianism, and psychopathy). Perspectives on Psychological Science, 12, 183-204.

Olweus, D. (2013): School bullying: Development and some important challenges. Annual Review of Clinical Psychology, 9, 751-780.

Pulkinen, L., Kaprio, J., Rose, R. J. (1999): Peers, teachers and parents as assessors of the behavioural and emotional problems of twins and their adjustment: The Multidimensional Peer Nomination Inventory. Twin Research, 2, 274-285.

Raine, A., Dodge, K., Loeber, R., Gatzke-Kopp, L., Lynam, D., Reynolds, Ch, Strouthamer-Loeber, M., Liu, J. (2006): The Reactive-Proactive Aggression Questionnaire: Differential correlates of reactive and proactive aggression in adolescent boys. Aggressive Behavior, 32, 159-171.

Rigby, K. (2012). Bullying in schools: Addressing desires, not only behaviours. Educational Psychology Review, 24, 339-348.

Ryckman, M.R., Kaczor, L.M., Gold, J.A. (1996): Construction of a Personal Development Competitive Attitude Scale. Journal of Personality Assessment, 66, 374-385.

Schwarzer, R., Jerusalem, M. (1995): Generalized Self-Efficacy scale. In J. Weinman, S. Wright, Johnston (Eds.) Measures in health psychology: A user's portfolio. Causal and control beliefs (pp. 3537). Windsor, UK: NFER-NELSON.

Smahel, D., Machackova, H., Mascheroni, G., Dedkova, L., Staksrud, E., Olafsson, K., Livingstone, S., Hasebrink, U. (2020): EU Kids Online 2020: Survey results from 19 countries. EU Kids Online.

Smith, P.K. (2019): School context. In R A Asor and R Bensenisthy (Eds.) Bullying, school violence, and climate in evolving contexts: Culture, organization and time. Oxford University Press.

Smith, P.K., Görzig, A., Robinson, S. (2018): Issues of cross-cultural variations in cyber-bullying across Europe and beyond. Media@ LSE Working Paper Series, WP 49, p.1-28.

Smith, P.K., Kwak, K., Toda, Y. (Eds.). (2016a): School bullying in different cultures: eastern and western perspectives. Cambridge: Cambridge University Press.

Smith, P.K., Kwak, K. \& Toda, Y. (2016b): Reflections on bullying in eastern and western perspectives. In P K Smith, K Kwak, Y Toda (Eds.) School bullying in different cultures: eastern and western perspectives (pp. 399-419). Cambridge: Cambridge University Press.

Triandis, H.C., Gelfand, M.J. (1998): Converging measurement of horizontal and vertical individualism and collectivism. Journal of Personality and Social Psychology, 74, 118-128.

Zimbardo, P. (2018): Exploring human nature and inspiring heroic social action. In A A Ariyanto, H Muluk, P Newcombe, F P Piercy, E K Poerwandari, S H R Suradijono (Eds.) Diversity in unity: Perspectives from psychology and behavioral science (pp. 3-9). Routledge/Taylor \& Francis Group.

\section{Szerzők}

Brassai László, Kovászna Megyei Erőforrás és Nevelési Tanácsadó Központ, Sepsiszentgyörgy, (Románia). E-mail: laszlobrassai@ gmail.com

Para Noémi, Kovászna Megyei Erőforrás és Nevelési Tanácsadó Központ, Sepsiszentgyörgy, (Románia). E-mail: para.noemi@yahoo.com 